\title{
The Determinants of International Portfolio Holdings and Home Bias
}

\author{
Hamid Faruqee, Shujing Li, \\ and Isabel K. Yan
}




\title{
IMF Working Paper
}

Research Department

\section{The Determinants of International Portfolio Holdings and Home Bias}

\author{
Prepared by Hamid Faruqee, Shujing Li, and Isabel K. Yan ${ }^{1}$ \\ Authorized for distribution by Tamim Bayoumi
}

February 2004

\begin{abstract}

\section{This Working Paper should not be reported as representing the views of the IMF.} The views expressed in this Working Paper are those of the author(s) and do not necessarily represent those of the IMF or IMF policy. Working Papers describe research in progress by the author(s) and are published to elicit comments and to further debate.

Despite the liberalization of foreign portfolio investment around the globe since the early 1980s, the home-bias phenomenon is still found to exist. Using a relatively new IMF survey dataset of cross-border equity holdings, this paper tests new structural equations from a consumption-based asset-pricing model on international portfolio holdings. Using of stock data allows us to provide new and clear-cut evidence on the determinants of international portfolio holdings. The empirical results show that an augmented gravity model performs remarkably well. The results indicate that market size, transaction cost, and information asymmetry are major determinants of cross-border portfolio choice. These findings shed light on alternative theories of international portfolio holdings, especially on the transaction and information cost-based explanations of home bias.
\end{abstract}

JEL Classification Numbers: G11; G15

Keywords: International portfolio choice; Home bias; Transaction cost; Information cost Authors’ E-Mail Addresses: ecli@stanford.edu; efyan@cityu.edu.hk; hfaruqee@imf.org

\footnotetext{
${ }^{1}$ The authors are thankful to Assaf Razin, Ronald McKinnon, Lawrence Lau, Michael Kumhof and the International Trade Seminar participants at Stanford University for helpful comments. All remaining errors are our own.
} 


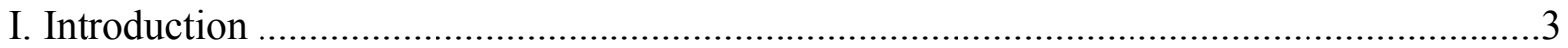

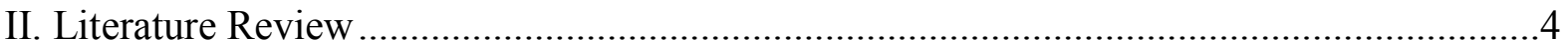

III. The Gravity Model of International Portfolio Holding............................................

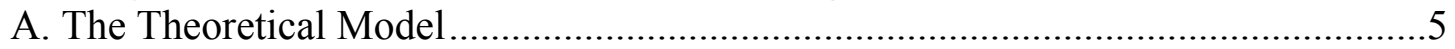

B. The Econometric Model of International Portfolio Holdings .................................8

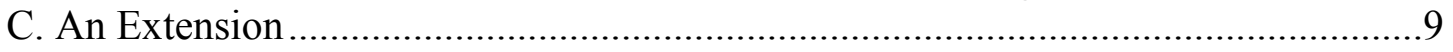

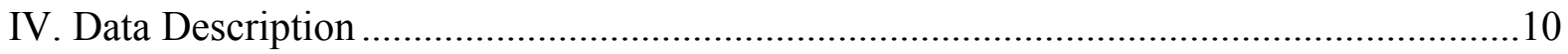

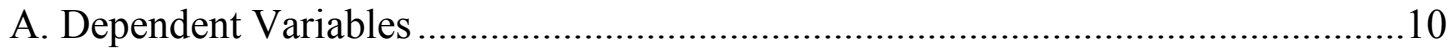

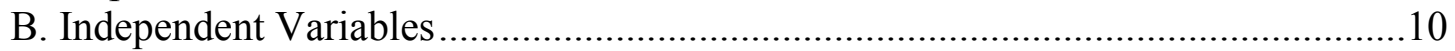

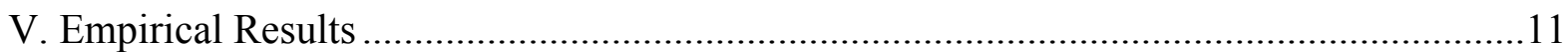

A. The Basic Gravity Model ............................................................................... 11

B. Information Cost Explanation and Return Chasing ......................................... 12

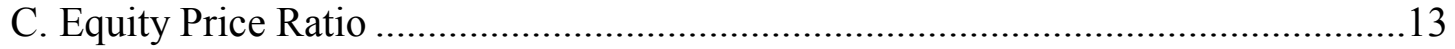

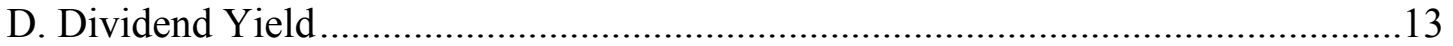

E. Portfolio Diversification of International CAPM ................................................ 14

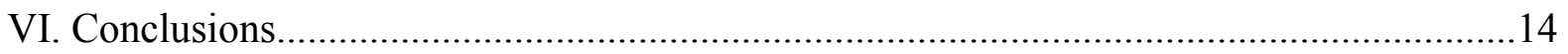

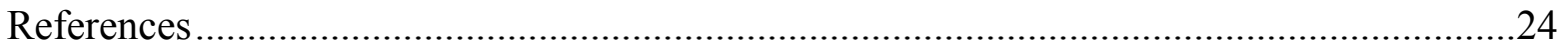

Tables

1. Percentage of Domestic Equity Holdings in Total Equity Holdings at the

End of Year 1997 and the Optimal Percentage.......................................................... 15

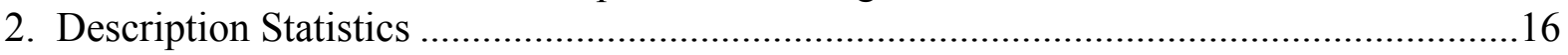

3. Correlation of Real Equity Return in 1987-97 ...................................................... 17

4. Estimation Results for the Equity-Holding Equations............................................ 18

5. Estimation Results for the Share-Ratio Equations.................................................. 19

Figures

1. Distribution of the International Equity Holdings of Australia, Austria, Belgium,

Canada, Denmark, and Finland in 1997.

2. Distribution of the International Equity Holdings of France, Ireland, Italy, Japan, Malaysia, and the Netherlands in 1997.

3. Distribution of the International Equity Holdings of New Zealand, Norway, Portugal,

Singapore, Spain, and Sweden in $1997 .$.

4. Distribution of the International Equity Holdings of the United Kingdom and the

United States in 1997 


\section{INTRODUCTION}

Theories of cross-border portfolio holdings are challenged by the "home-bias" puzzle, ${ }^{2}$ which refers to the fact that domestic investors hold too little of their wealth in foreign assets as compared with the predictions of standard portfolio theory. French and Poterba (1991) study international equity holdings and find that there is too little cross-border diversification given the correlation structure of the international equity markets, which provides great advantage for portfolio diversification. In addition, Tesar and Werner (1995) study the excess return on a portfolio of foreign securities compared with a portfolio including primarily domestic securities and find that there are significant gains to be made from international diversification in all countries of their sample (Canada, Japan, the United Kingdom and the United States) except Germany. In Table 1, we compare the observed domestic portfolio share with the prediction from the capital asset pricing model (CAPM). The classical CAPM assumes symmetry across agents and countries and predicts that agents worldwide hold the same market portfolio in which the fraction of investment at home is equal to the value of the domestic stock market relative to the value of the world stock market. Hence, the benchmark world market portfolio weight $w_{i}^{*}$ equals $m c p_{i} / \sum_{j} m c p_{j}$, where $m c p_{i}$ is the market capitalization of country $\mathrm{i}$.

Column (1) in Table 1 reports the observed percentage of domestic equity holdings in the total equity holdings of each country at the end of year 1997. Column (2) in Table 1 reports the benchmark prediction from CAPM. Column (3) shows the differences. The data indicate that the actual percentage of domestic asset holdings is much larger than that of the CAPM benchmark prediction for all countries in the sample. For example, Austria's actual domestic equity holdings are 300 times more than the prediction of CAPM.

This observation is puzzling because it implies that the investors forgo potentially large gains from international diversification. ${ }^{3}$ Numerous theoretical and empirical studies have attempted to provide explanations to this home-bias phenomenon. However, existing empirical works have been impeded by the problem of estimating cross-border holdings, which are stock measures. In addition, most of the empirical studies are restricted to the Group of Seven (G-7) countries. Portes and Rey (2000) is one of the exceptions. They study the determinants of crossborder equity flows among 14 countries using a trade-style gravity equation. Nevertheless, as pointed out in Warnock (2001), flow data provide an inaccurate measure of the cross-border equity holdings, since they are confounded by the turnover rate. Considering the lack of reliable measures of the turnover rate, the flow data provide little information about the determinants of international asset holdings (Lane, 2000; Warnock, 2001). Fortunately, in 1997, the IMF organized a coordinated survey of cross-border equity holdings in 29 countries. The results of this survey provide a relatively high-quality stock measure of the bilateral equity holdings among these 29 countries at the end of 1997 . This is the first time that econometric crosssectional analysis has been done on the bilateral portfolio holdings of a large sample of countries. The cross-border equity holdings of various countries in 1997 are shown in

${ }^{2}$ For an early reference, see Levy and Sarnat (1970).

${ }^{3}$ See Lewis (1999) for a detailed discussion of this home bias puzzle. 
Figures 1-4. The figures indicate that there is a wide dispersion in international equity holdings for the countries in the sample.

Within the vast theoretical and empirical literature, numerous explanations have been offered for the determinants of international portfolio choice and home bias. Among others, they include international diversification for hedging country-specific risk, transaction costs in buying and selling foreign securities, and information asymmetries. The purpose of this paper is not to add new explanations but to apply the Coordinated Portfolio Investment Survey (CPIS) dataset to test the validity of the aforementioned popular explanations in the existing literature. We first employ a highly stylized consumption-based asset-pricing model that accommodates transaction costs. This model implies that investment in foreign countries can bring diversification benefits but may be discouraged by the transaction costs. The CPIS dataset allows us to test the relationship between bilateral equity holdings and transaction costs. In the empirical study described in this paper, our sample includes 23 of those countries in the IMF CPIS dataset for which reliable macro data can be obtained ${ }^{4}$. We find that our model fits the data well. The market-size, information-costs and transaction-efficiency variables can explain nearly 80 percent of the variation of the cross-border equity holdings.

The structure of this paper is as follows. Section VI. represents a review of the relevant literature. Section III. presents a structural model on the determinants of international portfolio holdings and discusses the implications of the structural model on the empirical regressions.

Section IV. describes the data used in this study. Section VI. reports the empirical results and Section VI. concludes.

\section{Literature ReVIEW}

The international CAPM of Frankel (1982) provides an utility-maximization model of international asset diversification. The international CAPM implies that the total portfolio risk can be reduced by holding foreign assets whose returns are negatively correlated with the returns of the home country assets. This suggests that the cross-border equity holdings are (i) negatively related to the degree of correlation between the home and foreign assets (ii) positively related to the returns of the foreign assets. In this paper, these implications of the international CAPM are tested by including the returns of the home and foreign assets as well as their correlation in the regression. Our results support both implications of the international CAPM.

A new school of thought on the home bias puzzle focuses on the information-based explanations. Using a simple model of investor preference and behavior, French and Poterba (1991) demonstrates that information asymmetry can generate the same observed portfolio patterns as if the investors expect the domestic equity returns to be several hundred basis points

\footnotetext{
${ }^{4}$ The 23 countries include Australia, Austria, Belgium, Canada, Hong Kong SAR, Denmark, Finland, France, Germany, Ireland, Italy, Japan, Malaysia, the Netherlands, New Zealand, Norway, Portugal, Singapore, Spain, Sweden, Switzerland, the United Kingdom, and the United States.
} 
higher than the returns in the foreign markets. Gehrig (1993) models the information asymmetry between domestic and foreign assets by using a model where investors observe noisy signals of firms' returns with different degrees of precision. Domestic bias arises from better investor information about domestic stocks and foreign investments appear on average more risky. Hasan and Simaan (2000) derives the premium that an investor is willing to pay to buy the full information of the mean return vector and shows that rational investors would prefer home country dominstated portfolios over diversified portfolios if the variability of estimation errors far exceeds the variability of the mean return vector.

On the empirical side, Frankel and Schmukler (1997)'s findings from country mutual fund data support the hypothesis of asymmetric information, according to which the holders of the underlying assets have more information about local assets than country fund share holders. Similarly, using data on foreign stock ownership in Japan, Kang and Stulz (1995) find that foreign investors overweight shares of firms whose information are more readily available. These firms include large firms in the manufacturing industries and firms with good accounting performance etc. They find that there is no evidence that foreign ownership is related to the expected returns. Moreover, Portes and Rey (2000) shows that the gravity model explains the cross-border equity flows remarkably well as distance serves as a good proxy for information cost. In this paper, bilateral distance and linguistic liaison are used to measure the information asymmetry between domestic and foreign investors.

Further to the literature on the information-based explanations, Black (1974) and Stulz (1981) develop equilibrium models of international asset pricing that explain home bias by citing transaction cost frictions to international capital flows. However, Tesar and Werner (1995) suggest that transaction costs are unlikely to be an explanation for home bias. The reason is that a higher transaction cost on foreign investment should lead to lower turnover rates on the foreign components of the asset portfolios, but they find that the portfolio turnover rates are much higher for foreign than domestic assets. Their finding is influential but controversial. Warnock (2001) suggests that this under-weighted but overtraded puzzle in foreign equities could be due to the intrinsic problems in estimating the cross-border holdings (a stock measure) based on the capital flow data (a flow measure). Our regression results show that transaction costs related variables such as bilateral distance, bilateral phone costs, and communication infrastructure are significant factors that affect international investment.

\section{The Gravity Model of International Portfolio Holding}

In this paper, we first use a structural model to obtain the basic relationships between the international portfolio holdings and their determinants suggested in the literature.

\section{A. The Theoretical Model}

We relax the assumptions in Martin and Rey (1999) and extend their model to N countries. Each country populates with $n_{i}$ risk-averse immobile identical agents. In the first period, each agent $h_{i} \in\left\{1, \ldots \ldots, n_{i}\right\}$ in country $i$ is endowed with y units of a freely traded good (the numeraire) and a risky project $x_{h_{i}}$. They can either consume the good or buy shares of projects developed by others. In the second period, there are S exogenously 
determined and equally likely states of nature. The risky project $x_{h_{i}}$ is an Arrow-Debreu security with payoff $\delta_{i j} d_{h_{i}} \delta_{-}\{\mathrm{ij}\}$ in state $\mathrm{j}, \mathrm{j} \in\{1, \ldots, \mathrm{S}\}$, where $\delta_{i j}=1$ if $\mathrm{i}=\mathrm{j}$ and $\delta_{i j}=0$ if $\mathrm{i} \neq \mathrm{j}$. This assumption captures the feature that different projects and assets are imperfectly correlated so that assets are imperfect substitutes and diversification improves safety. For simplicity, we assume the dividend $d_{h_{i}}$ of the risky projects in the same country are the same. All the projects are traded in the competitive market with exogenous prices. In the first period, the agents raise capital by selling shares of their projects and they buy shares of other projects. $\mathrm{T}$ is the total number of projects in the world. We assume the number $\mathrm{S}$ of the total states of the world is always bigger than T, which means the market is not complete. Agents cannot eliminate all the risk by holding a portfolio of all traded assets. In some states of the world, there will be no production. In equilibrium, assume agents will have no interest in duplicating a project that has already been developed. Thus the total number of projects in the world is $T=\sum_{i=1}^{N} \sum_{h_{i}=1}^{n_{i}} x_{h_{i}}$.

We introduce international transaction costs in both trade and asset markets. In the first period, when agents trade assets the buyers of the assets bear the transaction cost. For example, denote $x_{h_{i}}^{h_{j}}$ (or $x_{h_{i}}^{j}$ in short) the demand of agent $h_{i}$ located in country $i$ for an asset developed by agent $h_{j}$ located in country $\mathrm{j}$. The amount paid by an agent $h_{i}$ to buy $x_{h_{i}}^{h_{j}}$ asset sold on the stock market in country $\mathrm{j}$ is $p_{h_{j}} x_{h_{i}}^{h_{j}}\left(1+\tau_{i}^{j}\right)$ where $p_{h_{j}}$ (or $p_{j}$ in short) is the price of a share of a project developed by agent $h_{j}$ and $\tau_{i}^{j}$ is the transaction cost in asset markets between country $i$ and country $\mathrm{j}$. In our paper, we assume the transaction cost between two countries is symmetric, i.e. $\tau_{i}^{j}=\tau_{j}^{i}$. In the second period, when the stochastic dividend is shifted across border, an iceberg cost (transportation cost) $\psi_{j}^{i}$ is applied. If an agent in country i holds an asset sold in country $\mathrm{j}$ which pays a dividend $d_{j}$ in period 2 , the shareholder in country $\mathrm{i}$ will receive only $\left(1-\psi_{j}^{i}\right) d_{j}$ per share.

Consumption goods and security in the second period is only differentiated by geography transaction cost. By perfect competition and the symmetry in our model, the securities within one country are homogeneous. We can write budget constraint for an agent $h_{i}$ in country i (home country) as,

$$
c_{1, h_{i}}+\sum_{j=1}^{N}\left(1+\tau_{i}^{j}\right) n_{j} p_{j} x_{h_{i}}^{j}=y+p_{h_{i}}
$$

where $\tau_{i}^{j}$ is the international transaction cost on financial market s.t. $\tau_{i}^{j}>0$ if $\mathrm{j} \neq \mathrm{i}$ and $\tau_{i}^{j}=0$ if $\mathrm{j}=\mathrm{i}$. Each agent $h_{i}$ in country i (in home country) maximizes the following utility,

$$
\underset{x_{h_{i}}^{n 1}, \ldots, x_{h_{i}}^{h_{N}}}{\operatorname{aax}} U_{h_{i}}=c_{1, h_{i}}+\beta E\left[c_{2, h_{i}}^{1-1 / \sigma} /(1-1 / \sigma)\right]
$$

Given the description of the payoff structure of the different projects, the expected utility of agent $h_{i}$ is,

$$
E\left[U_{h_{i}}\right]=c_{1, h_{i}}+\beta \frac{1}{T} \sum_{j=1}^{N}\left[n_{j}\left(\left(1-\psi_{i}^{j}\right) d_{j} x_{h_{i}}^{h_{j}}\right)^{1-1 / \sigma} /\left(1-\frac{1}{\sigma}\right)\right]
$$


where $\psi_{j}^{i}$ is the iceberg cost in trade s.t. $\psi_{j}^{i}>0$ if $\mathrm{j} \neq \mathrm{iand} \psi_{j}^{i}=0$ if $\mathrm{j}=\mathrm{i}$.

By the first order condition,

$$
\begin{aligned}
x_{h_{i}}^{h_{i}} & =\left(\frac{\beta}{T}\right)^{\sigma} \frac{d_{i}^{\sigma-1}}{p_{h_{i}}^{\sigma}} \\
x_{h_{i}}^{j} & =\left(\frac{\beta}{T}\right)^{\sigma} \frac{d_{j}^{\sigma-1}}{p_{j}^{\sigma}} \frac{\left(1-\psi_{i}^{j}\right)^{\sigma-1}}{\left(1+\tau_{i}^{j}\right)^{\sigma}} \text { for } \mathrm{j} \neq h_{i}
\end{aligned}
$$

The market clearing conditions are,

$$
\sum_{i=1}^{N} n_{i} x_{h_{i}}^{j}=1, j=1, \ldots . . N
$$

Then we get the cross-border equity holdings of $\mathrm{i}$ from $\mathrm{j}$,

$$
\begin{aligned}
e q_{i}^{j} & =n_{i} n_{j} p_{j} x_{i}^{j} \\
& =n_{i} n_{j} p_{j}\left(\frac{\beta}{T}\right)^{\sigma} \frac{d_{j}^{\sigma-1}}{p_{j}^{\sigma}} \frac{\left(1-\psi_{i}^{j}\right)^{\sigma-1}}{\left(1+\tau_{i}^{j}\right)^{\sigma}} \\
& =\left(\frac{\beta}{T}\right)^{\sigma}\left(m c p_{i}\right)\left(m c p_{j}\right)\left(T C_{i}^{j}\right)\left(R_{j}^{\sigma-1}\right) \frac{1}{p_{i} p_{j}}
\end{aligned}
$$

where $T C_{i}^{j}=\left(1-\psi_{i}^{j}\right)^{\sigma-1} /\left(1+\tau_{i}^{j}\right)^{\sigma}$ is the international transaction cost and $R_{j}=d_{j} / p_{j}$ is the rate of return. $m c p_{i}$ and $m c p_{j}$ are the market capitalization of country $i$ and $j$ respectively. From this equation, we obtain the gravity model of the cross-border portfolio holdings: the crossborder holdings are positively correlated with the market capitalization of country $i$ and $j$; the cross-border holdings are negatively correlated with the international transaction cost in trade and financial market; there is a return-chasing behavior and $p_{i}, p_{j}$ measures the price of country j's asset relative to country i's asset. By simple manipulation, we obtain the following equations which are equivalent to equation 1 ,

$e q_{i}^{j}=\left(\frac{\beta}{T}\right)^{\sigma} n_{i} n_{j}\left(T C_{i}^{j}\right)\left(R_{j}^{\sigma-1}\right)$

$\frac{s_{i}^{j}}{s_{j}^{j}}=\frac{p_{j}}{p_{i}} \frac{T C_{i}^{j}}{T C_{j}^{j}}$

$\frac{s_{i}^{j}}{s_{j}^{j}}=\frac{R_{j}}{R_{i}} \frac{T C_{i}^{j}}{T C_{j}^{j}} \frac{d_{j}}{d_{i}}$

where $s_{i}^{j}$ is the share of country i's portfolio consisting of country j's equity, which equal to $e q_{i}^{j} /\left(m c p_{i}\right)$. The international CAPM without transaction costs predicts that $s_{i}^{j}=s_{j}^{j}=m c p_{j} / \sum_{i} m c p_{i}$. However, we observe $s_{i}^{j} / s_{j}^{j}$ much smaller than 1 . The mean value is 0.02 in our sample. In the empirical section of this paper, we study whether transaction costs and asymmetric information can explain for the deviations of the actual bilateral equity holdings from the prediction of the international CAPM. 


\section{B. The Econometric Model of International Portfolio Holdings}

Assume the international transaction cost $T C_{i}^{j}$ is in Cobb-Douglas form. Hence,

$$
\begin{aligned}
\log \left(T C_{i}^{j}\right) & =\log \left(T C_{\text {Trade }}\right)+\log \left(T C_{\text {financial }}\right) \\
& =\beta X_{i}^{j}
\end{aligned}
$$

where $X_{i}^{j}$ is a $\mathrm{K} \times 1$ vector which contains the logarithm of transaction cost variables. $\beta$ is a $\mathrm{K} \times 1$ coefficient vector. The transaction costs variables employed in this paper include the distance $\left(\right.$ dist $\left._{i}^{j}\right)$, the reciprocal of bilateral openness $\left(1 /\right.$ biopen $\left._{i}^{j}\right)$, the number of phonelines ( phoneline $_{i}$ ) and the phone costs $\left(\right.$ phone $\left.\cos t_{i}\right)$. Since the sample countries had eliminated almost all capital controls on portfolio investment in the 1990s, no capital control index is explicitly included in the regression analysis.

Taking logarithm of equation 1 we derive the econometric equation:

$$
\begin{aligned}
& \log \left(e q_{i}^{j}\right)=\text { constant }+\beta_{1} \log \left(m c p_{i}\right)+\beta_{2} \log \left(m c p_{j}\right)+\beta_{3} \log \left(d i s t_{i}^{j}\right) \\
& +\beta_{4} \log \left(\text { inf ormation cost var iables }{ }_{i}^{j}\right)+\beta_{5} \log \left(\text { transaction cost variables }_{i}^{j}\right) \\
& +\beta_{6} \log \left(\text { return variables }_{j}\right)+\beta_{7} \log \left(\text { price }_{i}\right)+\beta_{8} \log \left(\text { price }_{j}\right)+\varepsilon_{i}^{j}
\end{aligned}
$$

The "log" operator denotes natural logarithm. The dependent variable $e q_{i}^{j}$ is the stock of country $j$ equity held by residents of country $i$ at the end of 1997. It is taken from the coordinated survey of cross-border equity holdings organized by the IMF. All equations include a constant term. When analyzing the international holding of equities, we used the beginning-of-period market capitalization $m c p_{i}$ and $m c p_{j}$ to represent the financial size of country i and country j respectively.

We use $d_{i s t}^{j} t_{i}$ to approximate the trading cost (including transaction cost and information cost). However, it is difficult to find an accurate measure corresponding to the concept of equilibrium price $\left(p_{i}\right.$ and $p_{j}$ ) of the model. Since $p_{i}$ and $p_{j}$ are endogenously related to the market capitalization $m c p_{i}$

and $m c p_{j}\left(m c p_{j}=\sum_{i=1}^{N} n_{i} x_{h_{i}}^{j} p_{j}\right)$, we cannot consistently estimate the coefficients of $m c p_{i}$ and $m c p_{j}$ in equation 5 if we omit the price variables and put them into the error term. For this reason, we use $G D P_{i}$ as a measure for the economic agent number $n_{i}$ in country $i$ and estimate equation 2 using the following econometric equation:

$$
\begin{aligned}
& \log \left(e q_{i}^{j}\right)=\text { cons } \tan t+\beta_{1} \log \left(G D P_{i}\right)+\beta_{2} \log \left(G D P_{j}\right)+\beta_{3} \log \left(\text { dist }_{i}^{j}\right) \\
& +\beta_{4} \log \left(\text { inf ormation } \cos t \text { variables }_{i}^{j}\right) \\
& +\beta_{5} \log \left(\text { transaction } \cos t \operatorname{var}_{\text {iables }_{i}^{j}}\right)
\end{aligned}
$$

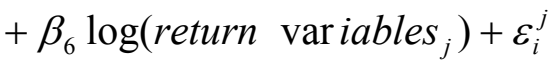

However, it is possible that some countries are financially less developed and may not use financial market to diversify their risks. For example, the price-economy ratio (mcp/GDP) of Italy was 0.25 in 1997, which was much smaller than Hong Kong's 2.7. Hence, for some cases, GDP may not be able to reflect fully the number of the economic agents who participate in the 
equity market. For this reason, we can instead estimate equation 4 as follows which does not involve the price variables:

$$
\begin{aligned}
& \log \left(s_{i}^{j} / s_{j}^{j}\right)=\text { cons } \tan t+\beta_{3} \log \left(\text { dist }_{i}^{j} / \text { dist }_{j}^{j}\right) \\
& +\beta_{4} \log \left(\text { inf ormation } \cos t \text { variables }_{\mathrm{i}}^{\mathrm{j}} / \inf \text { ormation } \cos t \operatorname{var}_{\text {iables }}^{\mathrm{j}}\right. \text { ) } \\
& +\beta_{5} \log \left(\text { transaction } \cos t \text { variables }_{i}^{j} / \text { transaction } \cos t \text { var }_{\text {iables }}^{j}\right) \\
& +\beta_{6} \log \left(\text { return variables } \text { / return }_{\text {variables }}\right)+\varepsilon_{i}^{j}
\end{aligned}
$$

Since it is not easy to obtain good measure of dividend $d_{i}$ in country $i$ either, we put it into the error term in the regression. However, although $d_{i}$ is exogenous, it is correlated with the return variables through the market clearing condition. Because of this, we need to use instrumental variables for the return variables in order to estimate the parameters consistently. Since the return variables are nonlinear functions of the transaction cost variables (e.g. dist $_{i}^{j}$ ) which are not likely to correlate with the dividend variables, we can use the square of the logarithm of those transaction cost variables as the instrumental variables for return variables and obtain consistent estimates of equation 4 using 2SLS.

\section{An Extension}

In the above structure model, we assume that the projects in different countries do not overlap with each other. This assumption can be easily relaxed. Suppose that different countries have some projects that overlap with each other ${ }^{5}$. In this case, the measure of economic scale in country $\mathrm{j}$ should be the projects which do not overlap with country i's. We define $G D P_{j}^{*}=G D P_{j} /\left(1+\operatorname{corr}_{i}^{j}\right)^{\beta}$, where $\operatorname{corr}_{i}^{j}$ is the correlation of returns between country $\mathrm{i}$ and $\mathrm{j}$ for the part of the country j's projects which do not overlap with home country i's. Under this specification, the bilateral correlation of returns is introduced into all of the above regressions. Table 3 shows the matrix of cross country correlations of real equity return in 1987-1997.

In the empirical section, we will firstly estimate a "core" equation which includes the three variables in equation $2\left(G D P_{i}, G D P_{j}\right.$ and $\left.d i s t_{i}^{j}\right)$. Then we will explicitly add other transaction cost variables to the estimation equation. Table 4 reports the results of regressions in which the dependent variables are $\log \left(e q_{i}^{j}\right)$. All regression estimates are White heteroskedasticity-consistent estimates.

\footnotetext{
${ }^{5}$ It is assumed that the transaction costs of international investments are nonzero so that it is always profitable to hold the home country's projects even though the same projects are available in other countries. In other words, it is assumed that $\left(d_{j}^{\sigma-1} / p_{j}^{\sigma}\right) T C_{i}^{j}<\left(d_{i}^{\sigma-1} / p_{h_{i}}^{\sigma}\right)$. This assumption is innocuous because, otherwise, no one will hold the home country projects at equilibrium.
} 


\section{DATA DESCRIPTION}

The cross-border equity data is from a survey of international portfolio holdings coordinated by the IMF. The countries that we have included in our sample are Australia, Austria, Belgium, Canada, Hong Kong (SAR), Denmark, Finland, France, Germany, Ireland, Italy, Japan, Malaysia, the Netherlands, New Zealand, Norway, Portugal, Singapore, Spain, Sweden, Switzerland, the United Kingdom, and the United States. Table 2 provides the descriptive statistics of all the variables. The data sources and definitions are summarized as follows:

\section{A. Dependent Variables}

$e q_{i}^{j}$ : equities of country $\mathrm{j}$ held by the residents of country i (in millions of US dollars) in 1997. Source: IMF, "Results of the 1997 Portfolio Investment Survey". Since Germany, Hong Kong SAR, and Switzerland are included in the survey as destination countries only but not as investing countries, the data set consists of 20 investing countries' holdings of 23 destination countries' equities at the end of 1997 . The equity data is thus a 20 by 23 matrix, which gives 460 observations in total.

$s_{i}^{j}$ : it equals to $e q_{i}^{j} / m c p_{i}$ where $m c p_{i}$ is the total market capitalization of equity in country $\mathrm{i}$ in 1997 (in billions of US dollars).

Source: MSCI.

\section{B. Independent Variables}

\section{Market Size:}

$G D P_{i}$ : the Gross Domestic Product at current price of country i (in millions of US dollars). NumFirm $_{i}$ : the number of publicly listed companies in country i.

\section{Information Cost Variables}

dist $_{i}^{j}$ : physical distance between the capital cities of country $\mathrm{i}$ and $\mathrm{j}$. When $\mathrm{i}=\mathrm{j}$, we take dist_\{ii $\}=1 \mathrm{~km}$. Source: $\underline{\text { www.ksg.harvard.edu/people/sjwei }}$

$\operatorname{Lin}_{i}^{j}$ : a dummy variable which equals to 1 if the official languages are the same in country $i$ and j, 0 otherwise. Source: www.ksg.harvard.edu/people/sjwei phoneline $_{i}$ : the number of main phone lines in use per 1000 inhabitants in country i. Source: "The World Competitiveness Yearbook", 1997 and 1999 issues, published by IMD.

\section{Transaction Cost Variables}

phone $\cos t_{i}$ : the per-minute international phone costs to call from country $\mathrm{i}$ to country $\mathrm{j}$ during business hours. Source: http://www.phone-rate-calculator.com 


\section{Asset Returns and Asset Prices}

averreturneq $_{j}$ : average real annual return of equity in country $\mathrm{j}$ (it includes the changes in the stock market indices and the dividend which is assumed to be reinvested monthly). The real return data is adjusted for the inflation rate and exchange rate movement in country $\mathrm{j}$ to take into account the influence of exchange rate changes (currency risk) and inflation on portfolio return. The $j^{\text {th }}$ real return is calculated as $r_{j}=\left[\left(1+i_{j}\right)\left(1+e_{j}\right) /\left(1+\pi_{j}\right)\right]-1$ where $i_{j}$ is the nominal return of an asset in its own currency, $e_{j}$ is the rate of appreciation of the home currency relative to the currency of the destination country and $\pi_{j}$ is the rate of inflation in the destination country. Source: return data is from MSCI monthly (entitled "MSCI" before 1996 and entitled "EAFE And World Prospective" starting 1996), inflation rate and exchange rate data are from IFS line ..AE.. and ..XZF.. respectively. $P E_{i}^{j}$ : The average price-earning ratio ( $\mathrm{P} / \mathrm{E}$ ratio) of equity in the destination country $\mathrm{j}$ divided by that of the source country i. Source: Global Financial Data -- MSCI P/E ratio.

\section{Openness of the Asset Market}

biopen $_{i}^{j}$ : (bilateral export of goods and services + bilateral import of goods and services) /2( in millions of US dollars ) between country $i$ and $j$, normalized by the average GDP of country $i$ and country j. Source: "Direction of Trade Statistics" 1997 issue, IMF.

\section{Portfolio Diversification}

correq $_{i}^{j}$ : The correlation of real equity return in country $\mathrm{i}$ and $\mathrm{j}$ between 1987 and 1997. Source: same as the variable averreturneq above.

\section{EMPIRICAL RESULTS}

\section{A. The Basic Gravity Model}

First we estimate the core equation which includes the market size and distance variables:

$$
\log \left(e q_{i}^{j}\right)=\text { cons } \tan t+\beta_{1} \log \left(G D P_{i}\right)+\beta_{2} \log \left(G D P_{j}\right)+\beta_{3} \log \left(\text { dist }_{i}^{j}\right)+\varepsilon_{i j}
$$

In this equation, the GDP variables capture the market sizes of the investing and destination countries while the distance variable provides a first-step approximation of the information cost. This core equation is a basic form of the gravity model which is actually a simplified form of equation 2 derived from the theoretical model. The information costs are expected to be positively correlated with distance as longer distance implies weaker business and cultural links, and the costs of face-to-face talk are higher. Thus distance is also a good proxy for the information cost in the financial market.

The estimation result is reported in Column (1) of Table 4. Equation 2 of the theoretical model predicts that the equity holding of country $\mathrm{i}$ in country $\mathrm{j}\left(e q_{i}^{j}\right)$ is directly and positively proportional to the market sizes $\left(n_{i}, n_{j}\right)$ and negatively proportional to the information costs. In particular, the model predicts that the cross-country equity holdings are negatively correlated 
with distance. The regression results show that all the coefficients of the variables are highly significant with the expected sign. Moreover, The estimated coefficients of the market size variables are statistically equal to one, which indicates that the cross-border equity holdings are directly proportional to the market size, as implied by the theoretical model. Furthermore, the positive relationship between cross-border portfolio holdings and domestic market size is consistent with Lane (2000)'s empirical finding that countries with larger domestic market size tend to holding greater quantity of foreign assets ${ }^{6}$.

These three independent variables can explain more than $64 \%$ of the variance of the cross-section equity holding data. This result shows that market sizes matter which is consistent with the theory of Martin and Ray (1999). This finding also supports the information asymmetry explanation of the home bias puzzle. In the next step, explicit transaction cost and information cost variables are added to the model.

\section{B. Information Cost Explanation and Return Chasing}

We now explicitly include more information and transaction cost variables ${\text { ( } \text { Lin }_{i}^{j} \text {, phontline }}_{i}$, phoneline ${ }_{j}$, phone $\cos t_{i}^{j}$, and biopen $_{i}^{j}$ ) and equity return variable of the destination country ( realreturn $_{j}$ ) into the regression to estimate equation 2 of the theoretical model $^{7}$. The regression then becomes

$$
\begin{aligned}
& \log \left(e q_{i}^{j}\right)=\text { cons } \tan t+\beta_{1} \log \left(G D P_{i}\right)+\beta_{2} \log \left(G D P_{j}\right)+\beta_{3} \log \left(\text { dist }_{i}^{j}\right) \\
& +\beta_{4} \text { Lin }_{i}^{j}+\beta_{5} \log \left(\text { phoneline }_{i}\right)+\beta_{6} \log \left(\text { phoneline }_{j}\right)
\end{aligned}
$$

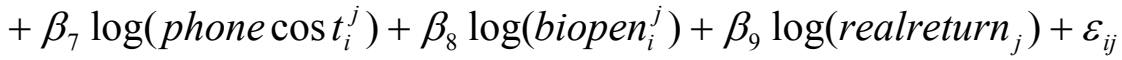

$\operatorname{Lin}_{i}^{j}$ is the dummy variables of linguistic and historical cultural links between country $i$ and country $\mathrm{j}$. The linguistic indicator measures the current communication cost. $\operatorname{Lin}_{i}^{j}$ is also an indicator for the accumulation of mutual knowledge between two countries. The estimates in column (2) of Table 4 show that the coefficient of $\operatorname{Lin}_{i}^{j}$ is significantly positive as suggested by the theory. As we will see, $\operatorname{Lin}_{i}^{j}$ is a very robust determinant of equity holdings. The coefficient

\footnotetext{
${ }^{6}$ Calvo and Mendoza(1999) explain for this positive relationship by using fixed costs in acquiring information about the investment conditions in a given country
}

${ }^{7}$ A possible alternative measure of transaction cost is to construct a transaction cost index using the principal eigenvector identified by the principal component analysis (PCA). The principal eigenvector assigns weights to the six transaction cost variables (including distance) so as to come up with an index (a weighted sum) which can best explain the percentage of variations of the six variables. Based on the PCA, 34 percent of the total variation can be explained by a transaction cost index formed by the first principal component. The variables (in log) ranked according to the absolute magnitude of their weights are: bilateral openness $(-0.557)$, phone cost $(0.554)$, distance $(0.519)$, phone line of the destination country $(-0.284)$, phone line of the investing country $(-0.164)$ and linguistic $(-0.059)$. 
of phoneline ${ }_{i}$ also shows up to be significantly positive and phone $\cos t_{i}$ significantly negative. This is exactly as predicted by the model since more phone lines and lower phone cost implies lower information and transaction costs between investors' home countries and the foreign countries. The estimates are reported in column (2) of Table 4. After adding these variables, the coefficients of dist $_{i}^{j}$ and the market size variables remain highly significant.

To analyze the return chasing motive implied by the international CAPM, we include the real return of the destination countries (realreturn $_{j}$ ) into the regression. This variable is only marginally significant at the $10 \%$ significance level. It provides an evidence that the returnchasing hypothesis of portfolio choice alone is not sufficient to explain for the cross-border equity holdings and the home bias puzzle.

\section{Equity Price Ratio}

The equity price ratio $\left(p_{j} / p_{i}\right)$ enters equation 3 of portfolio holding and we approximate it by the relative $\mathrm{P} / \mathrm{E}$ ratio in the investing and the destination countries. Our model predicts that a high relative price in the destination country will result in a high equity holding there. This is an evidence of the "herding" effect that was found in the stock market --- a high price now increases people's expectation about future price and thus encourages people to invest more in the stock market. Equation 3 of the theoretical model is estimated as follows:

$$
\begin{aligned}
& \log \left(s_{i}^{j} / s_{j}^{j}\right)=\text { cons } \tan t+\beta_{1} \log \left(P E_{j} / P E_{i}\right)+\beta_{2} \log \left(\text { dist }_{i}^{j} / \text { dist }_{j}^{j}\right) \\
& +\beta_{3} \operatorname{Lin}_{i}^{j}+\beta_{4} \log \left(\text { phoneline }_{i} / \text { phoneline }_{j}\right) \\
& +\beta_{5} \log \left(\text { phone } \cos t_{i}^{j} / \text { phone } \cos t_{j}^{j}\right)+\beta_{6} \log \left(\text { biopen }_{i}^{j}\right)+\varepsilon_{i j}
\end{aligned}
$$

As the equity price ratio may cause endogeneity problem, instrumental variables are used for it in the regression. Based on the market clearing condition, the equity price ratio is nonlinearly related to the transaction cost variables and market size variables. Because of this, variables related to transaction costs and market size (including $\log \left(G D P_{i}\right), \log \left(G D P_{j}\right), \log \left(\right.$ dist $\left._{i}^{j}\right), \log \left(\text { dist }_{i}^{j}\right)^{2}, \log \left(\right.$ NumFirms $\left._{i}\right)$ and $\log \left(\right.$ NumFirms $\left._{j}\right)$ are used as instrumental variables for equity price ratio to consistently estimate the parameters. The estimates are reported in column (1) of Table 5. The coefficient of the equity price ratio is significantly positive as predicted by equation 3 of the theoretical model. Also, the transaction costs variables (including dist ${ }_{i}^{j} /$ dist $_{j}^{j}{\text {, } \text { Lin }_{i}^{j} \text {, phoneline }}_{i} /$ phoneline $_{j}$ and biopen $_{i}^{j}$ ) are significant and of the correct signs.

\section{Dividend Yield}

The dividend ratio $\left(d_{j} / d_{i}\right)$ enters equation 4 of portfolio holding in the theoretical model. Nevertheless, since it is not easy to obtain a good measure of the country-wide dividend, we include the dividend in the error term of the regression. However, although $d_{i}$ is exogenous, it is correlated with the return variables through the market clearing condition. In regard of this, instrumental variables are used for the return variable in order to estimate the parameters consistently. As the return variables are nonlinear function of the transaction cost variables (e.g. dist_ $\left.\{i\}^{\wedge}\{j\}\right)$ which are not likely to correlate with the dividend variables, we use the square of 
the logarithm of those transaction cost variables as the instrumental variables for the return variable and obtain consistent coefficients for equation $<$ ref $>$ Equation $4</$ ref $>$. The estimation results are reported in column (3) of Table 5. The estimation results show that transaction cost are negatively related to the ratio of cross-border to domestic equity holdings, as indicated by equation $<$ ref $>$ Equation $4</$ ref $>$ of the theoretical model. Also, the real return variable shows up to be significantly positive, which supports the prediction of equation 4 of the model.

\section{E. Portfolio Diversification of International CAPM}

As the international CAPM also implies a negative relationship between international asset holding and the degree of correlation between the returns of home and foreign assets, we add the correlation of home and foreign asset returns ( $\left.\operatorname{corr}_{i}^{j}\right)$ into regressions 9, 10 and equation 4. The results are reported in column (3) of Table 4, column (2) and column (4) of Table 5 respectively. The correlation variables are all significantly negative at the 1 percent significance level, which supports the portfolio diversification implication of the international CAPM.

\section{Conclusions}

We find strong evidence of home bias in equities in 20 countries despite the general relaxation of controls on foreign portfolio investments by developed countries in the early 1980s. Our empirical findings shed light on the relevance of competing explanations of international portfolio choice and the home-bias puzzle. In our findings, international portfolio holdings are determined by market size, transaction costs, and information costs. The estimation results also support explanatory return-chasing behavior and portfolio diversification as implied by the international CAPM. These results suggest that international investing behavior is determined by multiple factors, which helps explain why single-factor models are inadequate in solving the home-bias puzzle.

Comparing competing explanations, we find that the gravity model performs best, with most of the explanatory power coming from the financial-market-size and distance variables. Therefore, we conclude that financial market size and information asymmetry are major determinants of international portfolio choice and home bias. This empirical finding is consistent with the implications of the theoretical model. 
Table 1. Percentage of Domestic Equity Holdings in Total Equity Holdings at the End of Year 1997 and the Optimal Percentage

\begin{tabular}{|c|c|c|c|}
\hline Country & $\begin{array}{c}\text { Actual Percentage of } \\
\text { Domestic Equity Held by } \\
\text { Domestic Investors } \\
\text { (1) }\end{array}$ & $\begin{array}{c}\text { Benchmark Percentage } \\
\text { (based on CAPM) } \\
(2)\end{array}$ & $\begin{array}{c}\text { "Home Bias" } \\
\text { (Actual minus } \\
\text { benchmark) } \\
\text { (3) }\end{array}$ \\
\hline Australia & 77.96 & 1.46 & 76.5 \\
\hline Austria & 65.82 & 0.20 & 65.62 \\
\hline Belgium & 70.37 & 0.67 & 69.70 \\
\hline Canada & 70.39 & 2.72 & 67.67 \\
\hline Denmark & 71.90 & 0.60 & 71.30 \\
\hline Finland & 88.44 & 0.39 & 88.05 \\
\hline France & 79.75 & 0.42 & 79.33 \\
\hline Ireland & 14.33 & 0.21 & 14.12 \\
\hline Italy & 78.31 & 2.12 & 76.19 \\
\hline Japan & 89.38 & 13.33 & 76.05 \\
\hline Malaysia & 96.61 & 0.44 & 96.15 \\
\hline Netherlands & 59.72 & 3.00 & 56.72 \\
\hline New Zealand & 68.57 & 0.16 & 68.41 \\
\hline Norway & 67.19 & 0.28 & 66.91 \\
\hline Portugal & 91.92 & 0.29 & 91.63 \\
\hline Singapore & 72.06 & 0.48 & 71.58 \\
\hline Spain & 86.38 & 1.41 & 84.97 \\
\hline Sweden & 69.55 & 1.37 & 68.18 \\
\hline United Kingdom & 69.37 & 11.43 & 57.94 \\
\hline United States & 85.45 & 55.20 & 30.25 \\
\hline
\end{tabular}

Source(s): CPIS, IMF (1997). 
Table 2. Description Statistics

\begin{tabular}{lcccc}
\hline \multicolumn{1}{c}{ Variables } & Mean & Std. Dev. & Min. & Max. \\
\hline & & & & \\
& & & & 215588 \\
Equities Holdings (in million USD) & 4777.5 & 17352.7 & 0 & 8300800 \\
GDP of the 20 investing countries (in million USD) & 967576.7 & 1894042.1 & 56854.5 & 8300800 \\
GDP of the 23 destination countries (in million USD) & 948075.9 & 1789728.4 & 56854.5 & 7.3917 \\
Phone cost ( in USD) & 3.1152 & 1.0542 & 0.3500 & 19870.5 \\
Distance (in km) & 6776.9 & 5774.1 & 173.50 & 1 \\
Linguistics ( dummy: 0 or 1) & 0.1795 & 0.3842 & 0 & 684.1 \\
Phone-lines of the 20 investing countries & 499.7 & 105.4 & 192.5 & \\
(per 1,000 in inhabitants) & & & & 684.1 \\
Phone-lines of the 23 destination countries & 512.2 & 103.8 & 192.5 & \\
(per 1,000 in inhabitants) & & & & 0.0204 \\
Bilateral openness (ratio) & 0.0005 & 0.0016 & 0 & 0.8951 \\
Correlation of equity returns between home and & 0.4785 & 0.1510 & 0.0916 & \\
destination countries & & & & 34.8247 \\
Real return of equity holdings (percent) & 18.0257 & 8.938 & -0.3970 & 65.7625 \\
\hline P/E ratio of equities & 22.1752 & 11.9012 & 12.2500 & \\
\hline
\end{tabular}

Source(s): CPIS, IMF (1997). 
Table 3. Correlation of Real Equity Return in 1987-97

\begin{tabular}{|c|c|c|c|c|c|c|c|c|c|c|c|c|}
\hline & $\mathrm{AU}$ & $\mathrm{AT}$ & $\mathrm{BE}$ & $\mathrm{CA}$ & HK & DK & FI & FR & GM & IE & IT & JP \\
\hline$\overline{\mathrm{AUU}}$ & (1.00 & 0.61 & 0.52 & 0.54 & 0.72 & 0.59 & 0.52 & 0.70 & 0.44 & $\begin{array}{l}0.70 \\
\end{array}$ & 0.25 & 0.63 \\
\hline $\mathrm{AT}$ & & 1.00 & 0.34 & 0.39 & 0.55 & 0.36 & 0.03 & 0.29 & 0.23 & 0.55 & -0.20 & 0.53 \\
\hline $\mathrm{BE}$ & & & 1.00 & 0.12 & 0.42 & 0.65 & 0.53 & 0.66 & 0.36 & 0.90 & 0.48 & 0.59 \\
\hline $\mathrm{CA}$ & & & & 1.00 & 0.87 & 0.09 & 0.43 & 0.29 & 0.11 & 0.34 & -0.11 & 0.14 \\
\hline HK & & & & & 1.00 & 0.28 & 0.34 & 0.66 & 0.34 & 0.33 & -0.10 & 0.38 \\
\hline DK & & & & & & 1.00 & 0.47 & 0.82 & 0.84 & 0.91 & 0.66 & 0.41 \\
\hline FI & & & & & & & 1.00 & 0.40 & 0.42 & 0.67 & 0.47 & 0.41 \\
\hline FR & & & & & & & & 1.00 & 0.80 & 0.87 & 0.62 & 0.48 \\
\hline GM & & & & & & & & & 1.00 & 0.92 & 0.70 & 0.24 \\
\hline $\mathrm{IE}$ & & & & & & & & & & 1.00 & 0.70 & 0.45 \\
\hline IT & & & & & & & & & & & 1.00 & -0.10 \\
\hline JP & & & & & & & & & & & & 1.00 \\
\hline
\end{tabular}

\begin{tabular}{|c|c|c|c|c|c|c|c|c|c|c|c|}
\hline & MY & NL & $\mathrm{NZ}$ & NO & $\mathrm{PT}$ & SG & SP & SE & $\mathrm{SZ}$ & UK & US \\
\hline$\overline{\mathrm{AUU}}$ & 0.52 & 0.62 & 0.70 & 0.48 & 0.29 & 0.67 & 0.55 & 0.73 & 0.27 & 0.29 & 0.34 \\
\hline $\mathrm{AT}$ & 0.41 & 0.40 & 0.66 & 0.22 & 0.19 & 0.67 & 0.40 & 0.37 & 0.34 & 0.47 & 0.48 \\
\hline $\mathrm{BE}$ & 0.16 & 0.56 & 0.27 & 0.35 & 0.44 & 0.20 & 0.75 & 0.67 & 0.31 & 0.42 & 0.34 \\
\hline $\mathrm{CA}$ & 0.75 & 0.37 & 0.84 & 0.31 & 0.33 & 0.61 & 0.47 & 0.36 & 0.13 & 0.34 & 0.04 \\
\hline HK & 0.89 & 0.42 & 0.91 & 0.38 & 0.28 & 0.87 & 0.49 & 0.28 & 0.27 & 0.31 & -0.09 \\
\hline DK & 0.21 & 0.85 & 0.17 & 0.80 & 0.49 & 0.34 & 0.67 & 0.82 & 0.44 & 0.63 & 0.48 \\
\hline FI & 0.31 & 0.60 & 0.51 & 0.67 & 0.61 & 0.20 & 0.73 & 0.69 & 0.37 & 0.19 & -0.14 \\
\hline FR & 0.47 & 0.81 & 0.35 & 0.70 & 0.48 & 0.53 & 0.56 & 0.76 & 0.35 & 0.48 & 0.51 \\
\hline GM & 0.28 & 0.89 & 0.25 & 0.89 & 0.69 & 0.41 & 0.52 & 0.66 & 0.62 & 0.64 & 0.50 \\
\hline IE & 0.13 & 0.98 & 0.59 & 0.80 & 0.85 & 0.29 & 0.95 & 0.89 & 0.76 & 0.85 & 0.63 \\
\hline IT & -0.24 & 0.71 & -0.03 & 0.52 & 0.68 & -0.17 & 0.60 & 0.52 & 0.59 & 0.55 & 0.44 \\
\hline JP & 0.51 & 0.29 & 0.41 & 0.39 & 0.09 & 0.59 & 0.26 & 0.55 & -0.01 & -0.12 & 0.03 \\
\hline MY & 1.00 & 0.29 & 0.63 & 0.46 & 0.15 & 0.89 & 0.20 & 0.31 & -0.05 & 0.04 & -0.15 \\
\hline NL & & 1.00 & 0.52 & 0.85 & 0.81 & 0.39 & 0.80 & 0.85 & 0.71 & 0.80 & 0.63 \\
\hline $\mathrm{NZ}$ & & & 1.00 & 0.39 & 0.56 & 0.68 & 0.60 & 0.44 & 0.39 & 0.38 & 0.21 \\
\hline $\mathrm{NO}$ & & & & 1.00 & 0.68 & 0.48 & 0.58 & 0.76 & 0.44 & 0.51 & 0.24 \\
\hline $\mathrm{PT}$ & & & & & 1.00 & 0.19 & 0.81 & 0.49 & 0.65 & 0.67 & 0.33 \\
\hline SG & & & & & & 1.00 & 0.24 & 0.32 & 0.15 & 0.15 & 0.06 \\
\hline SP & & & & & & & 1.00 & 0.72 & 0.59 & 0.76 & 0.38 \\
\hline $\mathrm{SE}$ & & & & & & & & 1.00 & 0.41 & 0.53 & 0.49 \\
\hline $\mathrm{SZ}$ & & & & & & & & & 1.00 & 0.61 & 0.57 \\
\hline UK & & & & & & & & & & 1.00 & 0.74 \\
\hline
\end{tabular}

Note: AU (Australia), AT (Austria), BE (Belgium), CA (Canada), HK (HongKong SAR), DK (Denmark), FI (Finland), FR (France), GM (Germany), IE (Ireland), IT (Italy), JP (Japan), MY (Malaysia), NL (Netherlands), NZ (N.Zealand), NO (Norway), PT (Portugal), SG (Singapore), SP (Spain), SE (Sweden), SZ (Switzer.), UK (United Kingdom), US (United States) 
Table 4. Estimation Results for the Equity-Holding Equations

\begin{tabular}{|c|c|c|c|}
\hline & (1) & $\begin{array}{c}\log \left(e q_{i}^{j}\right) \\
\quad(2)\end{array}$ & (3) \\
\hline \multirow[t]{2}{*}{ Constant } & -17.37 & -25.56 & -24.21 \\
\hline & $(-15.170)^{* *}$ & $(-9.090)^{* *}$ & $(-8.300)^{* *}$ \\
\hline \multirow[t]{2}{*}{$\log \left(\mathrm{GDP}_{\mathrm{i}}\right)$} & 1.224 & 1.039 & 1.001 \\
\hline & $(22.480)^{* *}$ & $(19.290)^{* *}$ & $(17.950)^{* *}$ \\
\hline \multirow[t]{2}{*}{$\log \left(\mathrm{GDP}_{\mathrm{j}}\right)$} & 0.951 & 0.981 & 0.967 \\
\hline & $(17.180)^{* *}$ & $(19.300)^{* *}$ & $(19.207)^{* *}$ \\
\hline \multirow[t]{2}{*}{$\log \left(\right.$ dist $\left._{\mathrm{ij}}\right)$} & -0.559 & -0.417 & -0.505 \\
\hline & $(-9.102)^{* *}$ & $(-7.810)^{* *}$ & $(-8.228)^{* *}$ \\
\hline \multirow[t]{2}{*}{$\operatorname{Lin}_{\mathrm{ij}}$} & -- & 1.015 & 1.122 \\
\hline & & $(5.365)^{* *}$ & $(5.805)^{* *}$ \\
\hline \multirow[t]{2}{*}{$\log \left(\right.$ phoneline $\left._{\mathrm{i}}\right)$} & -- & 1.916 & 2.009 \\
\hline & & $(7.344)^{* *}$ & $(7.490)^{* *}$ \\
\hline \multirow[t]{2}{*}{$\log \left(\right.$ phoneline $\left._{\mathrm{j}}\right)$} & -- & -0.099 & -0.092 \\
\hline & & $(-0.318)$ & $(-0.297)$ \\
\hline \multirow[t]{2}{*}{$\log \left(\right.$ phonecost $\left._{\mathrm{ij}}\right)$} & -- & -0.458 & -0.506 \\
\hline & & $(-2.812)^{* *}$ & $(-3.110)^{* *}$ \\
\hline \multirow[t]{2}{*}{$\log \left(\right.$ biopen $\left._{\mathrm{ij}}\right)$} & -- & 0.223 & 0.224 \\
\hline & & $(7.290)^{* *}$ & $(7.392)^{* *}$ \\
\hline \multirow[t]{2}{*}{$\log \left(\right.$ realreturn $\left.{ }_{\mathrm{j}}\right)$} & -- & 1.636 & 2.028 \\
\hline & & $(1.620)$ & (1.928) \\
\hline \multirow[t]{2}{*}{ correq $_{\mathrm{ij}}$} & -- & -- & -1.306 \\
\hline & & & $(-2.635)^{* *}$ \\
\hline$\overline{\overline{R^{2}}}$ & 0.6418 & 0.7907 & 0.7933 \\
\hline F statistics & 263.3 & 184.0 & 168.3 \\
\hline
\end{tabular}

Notes: 1 . The numbers in parentheses are the t-statistics. Standard errors are heteroskedasticity consistent.

2. "*" means the t-statistic is $5 \%$ significant.

3. "**" means the t-statistic is $1 \%$ significant. 
Table 5. Estimation Results for the Share-Ratio Equations

\begin{tabular}{|c|c|c|c|c|}
\hline & \multicolumn{4}{|c|}{$\begin{array}{c}\text { Dependent variable } \\
\log \left(s_{i}^{j} / s_{i}^{j}\right)\end{array}$} \\
\hline & (1) & (2) & (3) & (4) \\
\hline \multirow[t]{2}{*}{ Constant } & 0.383 & 3.427 & 0.531 & 3.667 \\
\hline & $(0.513)$ & $(3.015)^{* *}$ & $(0.722)$ & $(3.305)^{* *}$ \\
\hline \multirow[t]{2}{*}{$\log \left(\mathrm{PE}_{\mathrm{j}} / \mathrm{PE}_{\mathrm{i}}\right)$} & 0.827 & 0.949 & -- & -- \\
\hline & $(3.060)^{* *}$ & $(3.315)^{* *}$ & & \\
\hline \multirow[t]{2}{*}{$\log \left(\right.$ dist $\left._{\mathrm{ij}} / \mathrm{dist}_{\mathrm{jj}}\right)$} & -0.486 & -0.664 & -0.489 & -0.672 \\
\hline & $(-5.924)^{* *}$ & $(-6.941)^{* *}$ & $(-6.048)^{* *}$ & $(-7.192)^{* *}$ \\
\hline \multirow[t]{2}{*}{$\operatorname{Lin}_{i j}$} & 0.845 & 1.011 & 0.789 & 0.954 \\
\hline & $(2.967)^{* *}$ & $(3.350)^{* *}$ & $(2.803)^{* *}$ & $(3.406)^{* *}$ \\
\hline \multirow[t]{2}{*}{$\log \left(\right.$ phoneline $_{\mathrm{i}} /$ phoneline $\left._{\mathrm{j}}\right)$} & 0.523 & 0.515 & 0.134 & 0.108 \\
\hline & $(1.502)$ & $(1.492)$ & $(0.362)$ & $(0.296)$ \\
\hline \multirow[t]{2}{*}{$\log \left(\right.$ phonecost $_{\mathrm{ij}} /$ phonecost $\left._{\mathrm{jj}}\right)$} & -0.712 & -0.731 & -0.597 & -0.600 \\
\hline & $(-3.903)^{* *}$ & $(-4.029)^{* *}$ & $(-3.372)^{* *}$ & $(-3.451)^{* *}$ \\
\hline \multirow[t]{2}{*}{$\log \left(\right.$ biopen $\left._{\mathrm{ij}}\right)$} & 0.211 & 0.230 & 0.212 & 0.230 \\
\hline & $(5.067)^{* *}$ & $(5.497)^{* *}$ & $(5.151)^{* *}$ & $(5.646)^{* *}$ \\
\hline \multirow[t]{2}{*}{$\log \left(\right.$ realreturn $/$ / realreturn $\left.{ }_{\mathrm{j}}\right)$} & -- & -- & 3.545 & 3.714 \\
\hline & & & $(2.733)^{* *}$ & $(2.912)^{* *}$ \\
\hline \multirow[t]{2}{*}{ correq $_{\mathrm{ij}}$} & -- & -2.703 & -- & -2.764 \\
\hline & & $(-3.560)^{* *}$ & & $(-3.724)^{* *}$ \\
\hline$\overline{R^{2}}$ & 0.2454 & 0.2605 & 0.2611 & 0.2862 \\
\hline F statistics & 22.60 & 21.66 & 22.86 & 22.26 \\
\hline
\end{tabular}

Note: 1 . The numbers in parentheses are the t-statistics. Standard errors are heteroskedasticity consistent.

2. "*" means the t-statistic is $5 \%$ significant.

3. "**" means the t-statistic is $1 \%$ significant. 
Figure 1. Distribution of the International Equity Holdings of Australia, Austria, Belgium, Canada, Denmark, and Finland in 1997
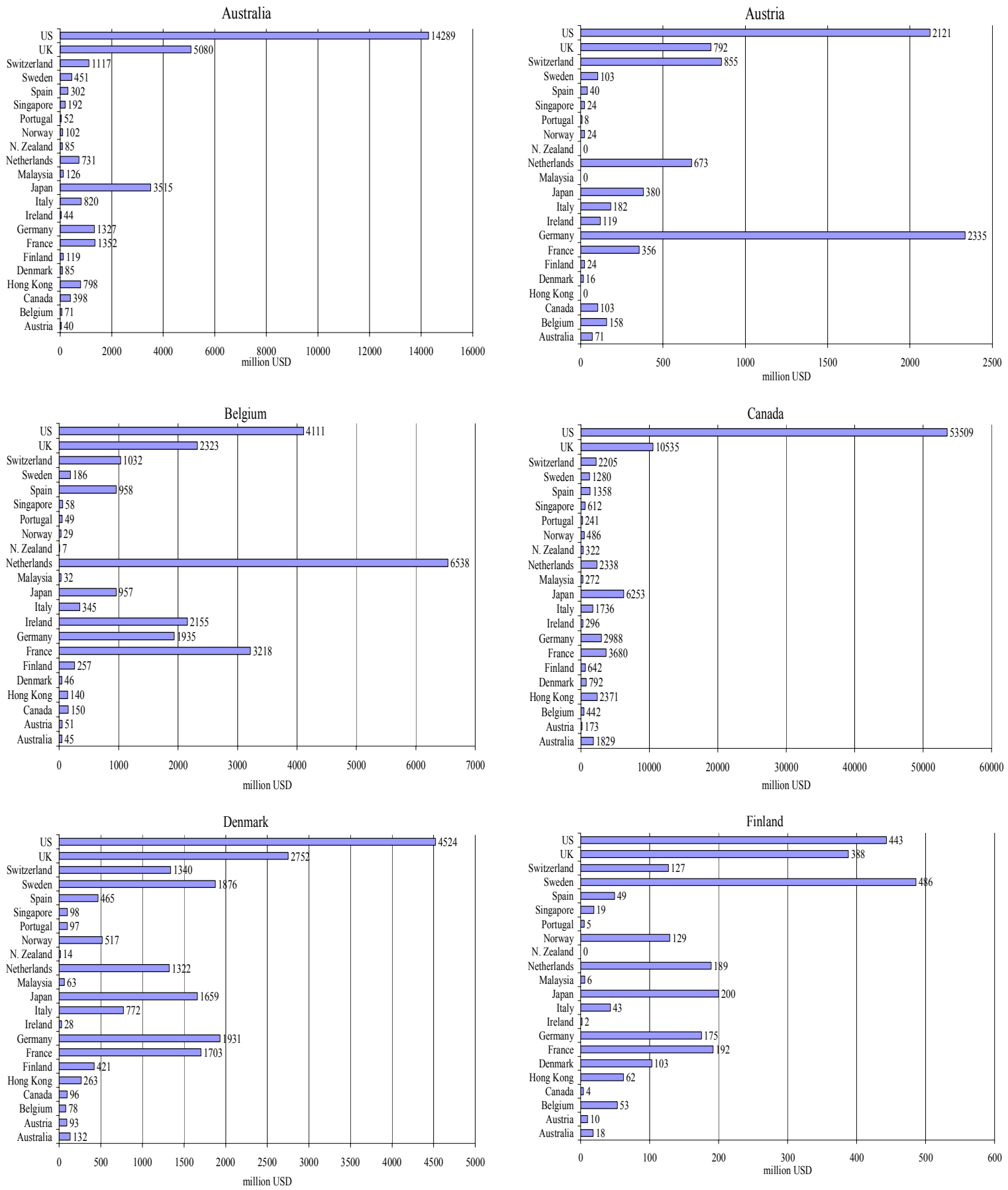

Source(s): CPIS, IMF (1997). 
Figure 2. Distribution of the International Equity Holdings of France, Ireland, Italy, Japan, Malaysia, and the Netherlands in 1997
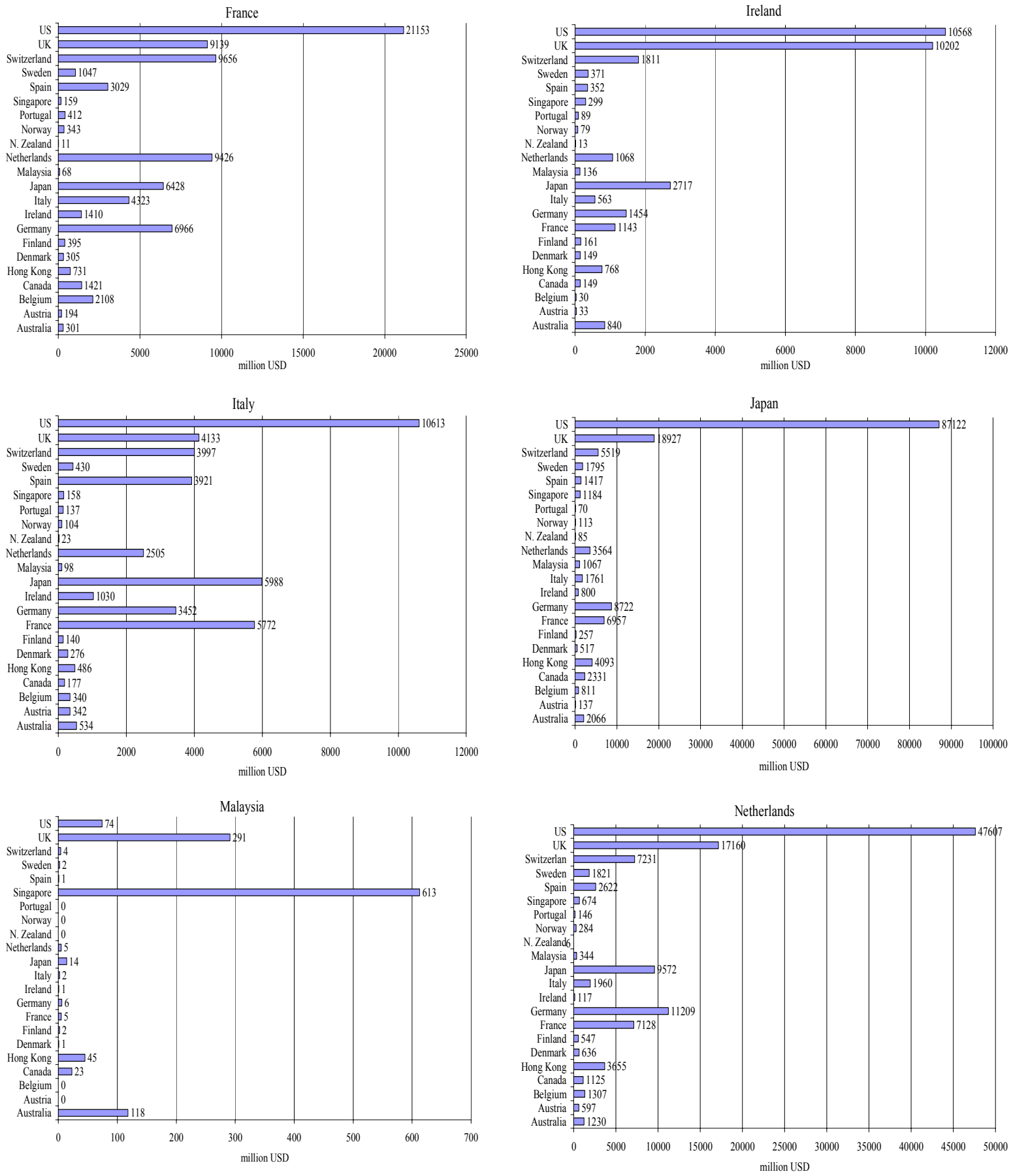

Source(s): CPIS, IMF (1997). 
Figure 3. Distribution of the International Equity Holdings of New Zealand, Norway, Portugal, Singapore, Spain, and Sweden in 1997
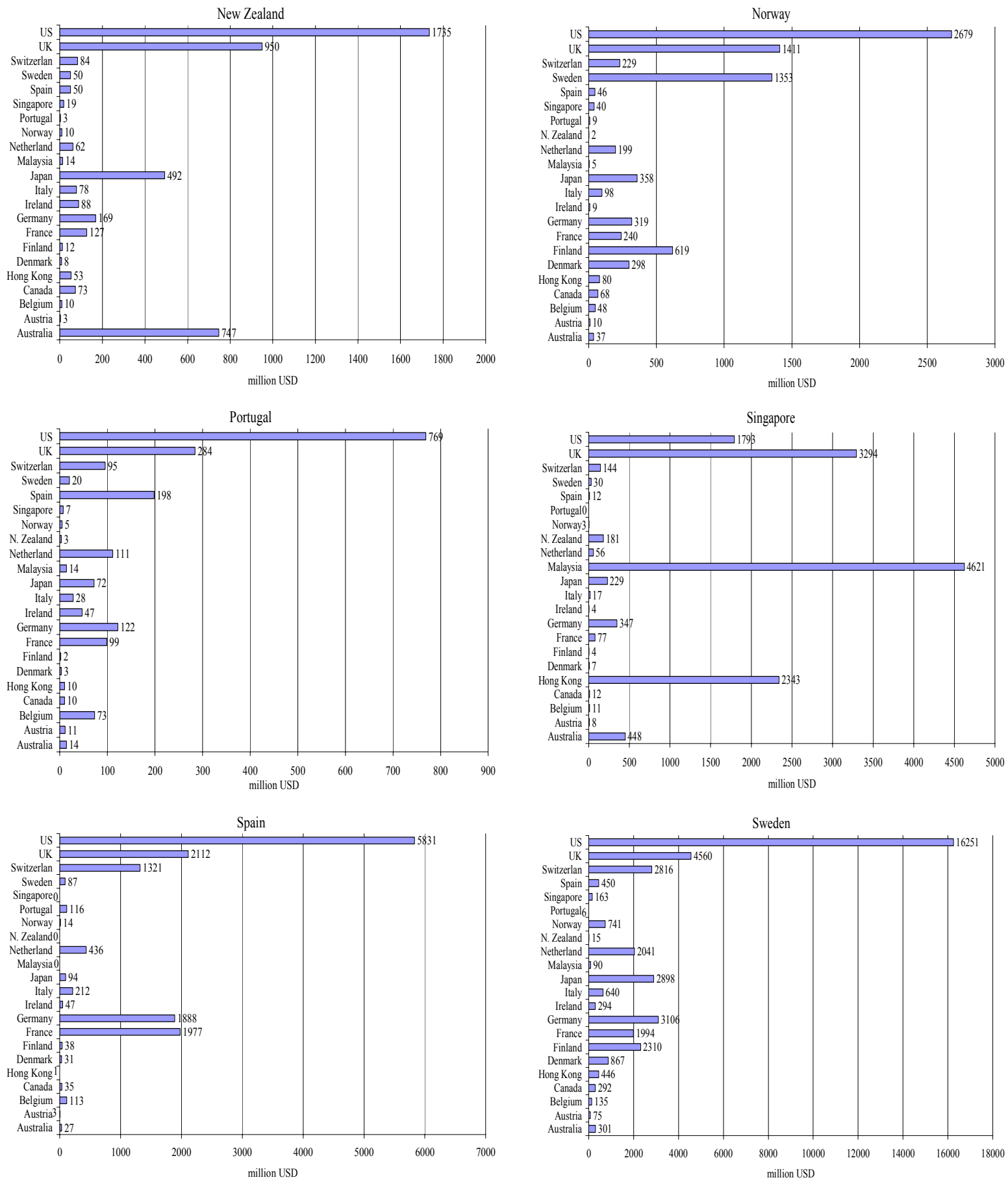

Source(s): CPIS, IMF (1997). 
Figure 4. Distribution of the International Equity Holdings of the United Kingdom and the United States in 1997
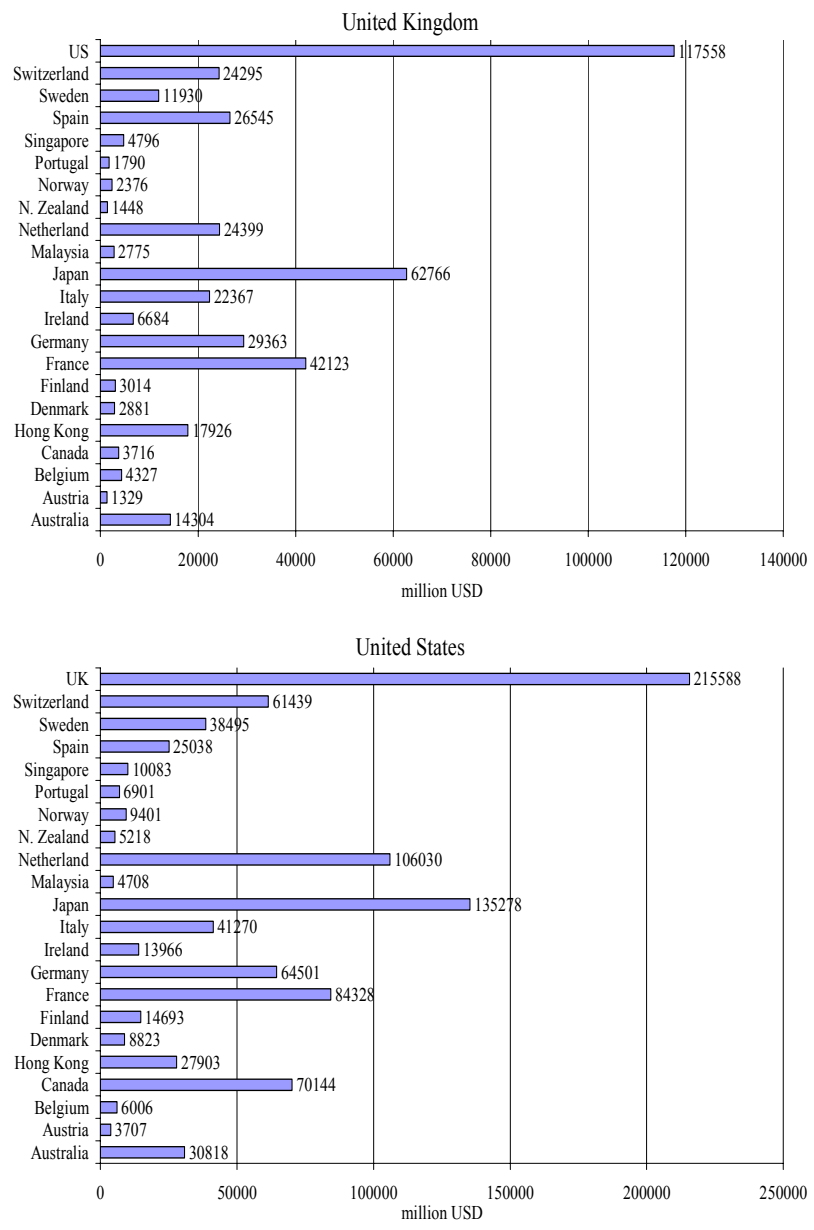

Source(s): CPIS, IMF (1997). 


\section{References}

Adler, Michael, and Bernard Dumas, 1983, "International Portfolio Choice and Corporation Finance: A Synthesis,” Vol. XXXVIII, No. 3, pp. 925-84.

Anderson, James, 1979, "A Theoretical Foundation for the Gravity Equation," American Economic Review, Vol. 69, No. 1, pp 106-116.

Brennan, Michael, and H. Cao, 1997, "International Portfolio Investment Flows," Journal of Finance, Vol. 52:5, pp. 1851-80.

Calvo, G., Mendoza, E., 1999, "Rational Contagion and the Globalization of Securities Markets,” NBER Working Paper No. 7153 (Cambridge, Massachusetts: National Bureau of Economic Research).

Clemens, Sialm, 1999, "International Asset Diversification and the Exchange Rate Risk Premium," Working Paper.

Coakley, Jerry, F. Kulasi, and R. Smith, 1998, “The Feldstein-Horioka Puzzle and Capital Mobility: A Review," International Journal of Finance and Economics, Vol. 3, pp. 169-188.

Coordinated Portfolio Investment Survey, 1997, IMF (Washington: International Monetary Fund).

Dumas, Bernard, and R. Uppal, 1998, "Global Diversification, Growth and Welfare with Imperfectly Integrated Markets for Goods," IMF, Working Paper.

Frankel, J., 1982, “A Search of the Exchange Risk Premium: A Six-Currency Test Assuming Mean-Variance Optimization," Journal of International Money and Finance, Vol. 1, pp. 255-274.

Frankel, Jeffrey and S. Schmukler, 1997, "Country Funds and Asymmetric Information," CIDER Working Paper No. C97-087, pp. 1-61 (Berkeley, CA: Center For International And Development Economics Research).

French, Kenneth, and J. Poterba, 1991, "Investor Diversification and International Equity Markets," American Economic Review, Vol. 81, pp. 222-26.

Gehrig, Thomas, 1993, "An Information Based Explanation of the Domestic Bias in International Equity Investment," Scand. J. Economics, Vol. 95:1, pp. 97-109.

Gordon, Roger H., and Lans A. Bovernberg, 1996, "Why is Capital So Immobile Internationally? Possible Explanations and Implications for Capital Income Taxation," American Economic Review, Vol. 86, pp. 1057-1075. 
Grinblatt, Mark, and M. Keloharju, 1999, “What Makes Investors Trade?,” UCLA, Working Paper.

Hasan, Ifekhar, and SimaanYusif, 2000, “A Rational Explanation for Home Country Bias,” Journal of International Money and Finance, Vol. 19, pp. 331-361.

Isard, Peter, 1977, "How Far Can We Push The Law of One Price?” American Economic Review, Vol. 67, 942-48.

Kang, Jun-Koo, and R. Stulz, 1997, "Why Is There Home Bias? An Analysis of Foreign Portfolio Equity Ownership in Japan," Journal Financial Economics, Vol. 46:1, pp. 3-28.

Lane, Philip and T. Dubin, 2000, "International Investment Position: A CrossSectional Analysis," Journal of International Money and Finance, Vol. 19:4, pp. 513-34.

Lewis, Karen, 1999, "Trying to Explain Home Bias in Equities and Consumption," Journal of Economic Literature, Vol. XXXVII, pp. 571-608.

Martin, Philippe, and H. Rey, 1999, "Financial Super-Markets: Size Matters for Asset Trade,” No. 2232, Pp. 1-25 (London, UK: Centre For Economic Policy Research. Discussion Paper Series).

Obstfeld, Maurice, and K. Rogoff, 2000, "The Six Major Puzzles in International Macroeconomics: Is There a Common Cause?," NBER Working Paper No. 7777, pp. 1-64 (Cambridge, Massachusetts: National Bureau of Economic Research).

Pesenti, Paolo, and E. Wincoop, 1998, “An International Benchmark Portfolio: The Role of Non-Traded Goods," NBER, Working Paper.

Portes, Richard, and H. Rey, 2000, "The Determinants of Cross-Border Equity Flows: The Geography of Information," CEPR .

Tesar, Linda, and I. Werner, 1995, "Home Bias and High Turnover," Journal of International Money and Finance, Vol., 14(4), pp 467-92.

Timmermann, Allan, and D. Blake, 2000, “International Investment Performance: Evidence from Institutional Investors' Foreign Equity Holdings," Working Paper.

Warnock, Francis E., 2001, "Home Bias and High Turnover Reconsidered, Board of Governors of the Federal Reserve System," International Finance Discussion Papers Number 702 . 